\title{
RESPONSE OF OPTIMUM NITROGEN RATE IN MAIZE WITH LEGUME INTERCROPPING SYSTEM
}

\author{
M.S.P. Naik, V. Sumathi" and L. Kadiri \\ Department of Agronomy, S.V. Agricultural College, Tirupati-517502, Andhra Pradesh, India
}

\begin{abstract}
A field experiment was conducted at S.V. Agricultural College farm (ANGRAU), Tirupati, India during rabi, 2009-10. The experiment was consisted of five system treatments (sole maize at $60 \times 20 \mathrm{~cm}$ sowing, sole maize in skipped row sowing, maize in skipped row + greengram, maize in skipped row + blackgram and maize in skipped row + cluster bean) and three nitrogen doses (100, 75 and 50\% recommended dose of nitrogen). The treatment combinations were laid out in factorial randomized block design with three replications. Yield attributes and grain yield of maize were maximum with sole maize at $60 \times 20 \mathrm{~cm}$ spacing but at par with maize + cluster bean, maize + blackgram and maize + greengram intercropping system. The lowest parameters were observed with sole maize sown in skipped rows. All the parameters were maximum with the application of $100 \%$ recommended dose of nitrogen to maize, but comparable with that of $75 \%$. The maize equivalent yield, land equivalent ratio and benefit cost ratio were higher with maize + cluster bean intercropping as compared to other treatments. The result revealed that among the different maize intercropping systems tested, maize in skipped rows + cluster bean with $75 \%$ recommended dose of nitrogen to maize was found economically profitable.
\end{abstract}

Keywords: Intercropping, legume, LER, maize, nitrogen doses, yield and BCR

\section{INTRODUCTION}

The sustainable productivity of crops is the need in the present Indian farming. Hence, possibility for crop intensification with sustainable nutrition for achieving the sustainability is urgently required. Hybrid maize being an exhaustive crop, requires high quantity of nutrients particularly nitrogen. The recent maize hybrids are responding to more than $240 \mathrm{~kg} \mathrm{~N} \mathrm{ha}^{-1}$. But, due to high cost and rate of fertilizer specially nitrogen, the farmers do not apply adequate quantity. In the present day's concern about environmental degradation coupled with high cost of nitrogen, there is

*Corresponding author email: lalithaprakash03@gmail.com

Received: 06.04.2017 
a need to find out supplemental alternative sources. Legumes, if associated with maize can minimize nitrogen requirement to some extent, besides maintaining soil health. Hence, the present study was designed to explore the possibilities of intercropping of short duration legumes under varied doses of nitrogen to maize.

\section{MATERIALS AND METHODS}

A field experiment was conducted at S.V. Agricultural College farm (ANGRAU), Tirupati, India during rabi, 2009-10. The experiment consisted of five system treatments (sole maize at $60 \times 20 \mathrm{~cm}$ sowing, sole maize in skipped row sowing, maize in skipped row + greengram, maize in skipped row + blackgram and maize in skipped row + cluster bean) and three nitrogen doses (100, 75 and 50\% recommended dose of nitrogen). The treatment combinations were laid out in factorial randomized block design with three replications. The results of physicochemical analysis of soil revealed that the soil was sandy clay loam in texture, near neutral in soil reaction, low in organic carbon and available nitrogen and medium in available phosphorus and potassium. The data pertaining to different weather parameters during the crop growth recorded at the meteorological observatory, S.V. Agricultural College Farm, Tirupati are presented in table 1. The test varieties of maize, greengram, blackgram and cluster bean were DHM-117, LGG-460, LBG-623 and RGM-112, respectively. Healthy seeds of maize and intercrops greengram, blackgram and cluster bean were treated with Mancozeb @ $3 \mathrm{~g} \mathrm{~kg}^{-1}$ of seed and sown @ 2 seeds hill ${ }^{-1}$ on 6 November 2009. Intercrops were sown at a spacing of $60 \times 5$ $\mathrm{cm}$. Uniform dose of $60 \mathrm{~kg} \mathrm{P}_{2} \mathrm{O}_{5}$ and $50 \mathrm{~kg} \mathrm{~K}_{2} \mathrm{O}^{-1}$ through Single super phosphate and Muriate of potash, respectively were applied as basal to the maize in all the plots. Nitrogen was applied as per the treatments in three equal splits viz., basal, knee height and at tasseling stage. Recommended dose of nitrogen applied to maize was $240 \mathrm{~kg} \mathrm{ha}^{-1}$. For the intercrops of greengram, blackgram and cluster bean 20, 50 and $40 \mathrm{~kg} \mathrm{~N}, \mathrm{P}_{2} \mathrm{O}_{5}$ and $\mathrm{K}_{2} \mathrm{O} \mathrm{ha}{ }^{-1}$ respectively, were applied as basal. Gap filling was done at one week after sowing, to maintain desired population as per treatments. Thinning was carried out at one week after sowing, to retain one seedling hill ${ }^{-1}$. Weeding was done twice at 15 and 30 days after sowing with rotary weeder followed by hand hoeing to keep the crop free from weeds. Spraying of chlorpyriphos @ $2.5 \mathrm{ml} \mathrm{l}^{-1}$ once and thiodicarb @ $1 \mathrm{~g}^{-1}$ water was sprayed twice to protect the crops from Spodoptera litura. Maize and intercrops were harvested when the sheaths of the cobs and pods were completely dried, respectively. Date of harvests of greengram, blackgram, clusterbean and maize were 7 January 2010, 19 January 2010, 20 January 2010 and 25 February 2010 respectively. The cobs of maize and pods of intercrops from net plot area were sun dried, threshed, cleaned and weighed separately. The total cost of cultivation was calculated for each treatment on the basis of inputs used. Gross returns were calculated based on the prevailing market price output. Net returns were arrived at by subtracting the cost of cultivation of respective treatment from gross returns of the corresponding treatment. Benefit cost ratio was calculated by dividing 
the gross returns with cost of cultivation of the respective treatments. The data was statistically analyzed by following the method of analysis of variance as suggested by Panse and Sukhatme (1985). Critical difference was worked out at $5 \%$ level of probability, where ever the treatmental differences were significant.

\section{RESULTS AND DISCUSSION}

\section{Yield attributes of maize}

Cob length: The length of the dehusked cobs of maize was significantly influenced by maize + legume intercropping and dose of nitrogen application to maize (Table 2). The longest cobs was observed in sole maize sown at $60 \times 20 \mathrm{~cm}$ which was closely followed by cob lengths recorded in maize + cluster bean, maize + blackgram and maize + greengram intercropping systems. The shortest cobs were recorded when sole maize sown in skipped rows. Among the nitrogen management, application of recommended dose of nitrogen to maize resulted in longest cob length which was comparable with that of 75 per cent recommended dose of nitrogen application and both were significantly superior to application of nitrogen at 50 per cent recommended dose.

Table 1 . Weekly meteorological data during the crop growth period (2009 - 2010)

\begin{tabular}{|c|c|c|c|c|c|c|c|c|c|c|c|c|c|c|c|}
\hline \multirow[t]{2}{*}{$\begin{array}{l}\text { Standard } \\
\text { week }\end{array}$} & \multirow[t]{2}{*}{$\begin{array}{l}\text { Date and } \\
\text { month }\end{array}$} & \multicolumn{4}{|c|}{ Temperature $\left({ }^{\circ} \mathrm{C}\right)$} & \multicolumn{2}{|c|}{$\begin{array}{c}\text { Relative } \\
\text { humidity }(\%)\end{array}$} & \multicolumn{2}{|c|}{ Rainfall (mm) } & \multicolumn{2}{|c|}{$\begin{array}{c}\text { No. of rainy } \\
\text { days }\end{array}$} & \multicolumn{2}{|c|}{$\begin{array}{c}\text { Mean } \\
\text { evaporation } \\
(\mathrm{mm})\end{array}$} & \multicolumn{2}{|c|}{$\begin{array}{c}\text { Mean bright } \\
\text { sunshine } \\
\text { (hours day }{ }^{-1} \text { ) }\end{array}$} \\
\hline & & A & $\mathrm{DN}$ & A & $\mathrm{DN}$ & A & $\mathrm{DN}$ & A & DN & A & $\mathrm{DN}$ & A & $\mathrm{DN}$ & A & DN \\
\hline 45 & 05-11 Nov & 27.2 & -2.6 & 22.5 & 1.5 & 85.2 & 11.5 & 111.4 & 84.4 & 5.0 & 3.3 & 1.6 & -1.8 & 1.1 & -4.2 \\
\hline 46 & $12-18 \mathrm{Nov}$ & 29.9 & 0.0 & 23.3 & 3.5 & 74.9 & 6.6 & 22.4 & 8.8 & 2.0 & 0.9 & 2.6 & -1.6 & 3.1 & -3.8 \\
\hline 47 & $19-25 \mathrm{Nov}$ & 31.6 & 3.6 & 22.2 & 2.0 & 71.0 & -2.0 & 15.0 & -29.9 & 1.0 & -0.9 & 3.2 & -0.3 & 6.1 & 0.7 \\
\hline 48 & 26-2 Dec & 29.4 & 1.4 & 20.4 & 1.3 & 66.8 & -4.8 & 0.0 & -49.2 & 0.0 & -1.6 & 4.3 & 0.7 & 6.5 & 0.5 \\
\hline 49 & 3-9 Dec & 28.7 & 0.4 & 19.6 & 1.6 & 71.5 & 1.4 & 14.2 & -8.8 & 2.0 & 1.0 & 2.5 & -1.2 & 3.9 & -3.3 \\
\hline 50 & $10-16 \mathrm{Dec}$ & 28.7 & 0.4 & 21.0 & 3.2 & 67.4 & -1.3 & 33.2 & 29.8 & 1.0 & 0.6 & 2.6 & -1.3 & 4.3 & -2.3 \\
\hline 51 & $17-23 \mathrm{Dec}$ & 27.5 & -0.8 & 19.3 & 1.8 & 72.3 & 2.4 & 14.7 & -15.5 & 3.0 & 2.2 & 2.2 & -1.5 & 2.4 & -3.9 \\
\hline 52 & 24-31 Dec & 28.1 & -0.8 & 18.3 & 0.9 & 67.6 & -2.0 & 0.0 & -4.5 & 0.0 & -0.5 & 2.6 & -1.4 & 4.2 & -2.6 \\
\hline 1 & 1-7 Jan & 29.1 & 0.7 & 17.0 & -0.5 & 68.8 & 0.8 & 0.0 & -4.2 & 0.0 & -0.2 & 3.5 & -0.6 & 5.3 & -2.1 \\
\hline 2 & 8-14 Jan & 29.8 & 0.9 & 20.6 & 4.0 & 67.4 & -0.6 & 0.0 & -0.5 & 0.0 & 0.0 & 3.4 & -1.1 & 4.7 & -2.8 \\
\hline 3 & 15-21 Jan & 30.0 & 0.3 & 18.4 & 2.4 & 61.6 & -4.3 & 0.0 & 0.0 & 0.0 & 0.0 & 4.5 & -0.3 & 6.8 & -1.5 \\
\hline 4 & 22-28 Jan & 29.5 & -1.4 & 16.6 & -1.3 & 61.3 & -2.1 & 0.0 & 0.0 & 0.0 & 0.0 & 4.5 & -0.4 & 8.1 & 0.2 \\
\hline 5 & 29-4 Feb & 30.1 & -0.8 & 15.7 & -2.5 & 60.4 & -4.9 & 0.0 & -0.6 & 0.0 & -0.2 & 4.4 & -0.5 & 7.9 & 0.2 \\
\hline 6 & 5-11 Feb & 30.7 & -0.9 & 16.3 & -1.7 & 58.6 & -2.0 & 0.0 & -1.5 & 0.0 & -0.1 & 5.4 & -0.1 & 8.3 & 0.1 \\
\hline 7 & $12-18 \mathrm{Feb}$ & 32.1 & -0.4 & 19.8 & 1.6 & 59.8 & -0.5 & 0.0 & 0.0 & 0.0 & 0.0 & 4.9 & -1.0 & 7.3 & -1.6 \\
\hline 8 & 19-25 Feb & 35.0 & 1.8 & 22.0 & 3.8 & 52.8 & -3.9 & 0.0 & -2.9 & 0.0 & -0.1 & 5.4 & -0.8 & 8.7 & 0.0 \\
\hline
\end{tabular}

A- Actual DN- Deviation from decennial mean 
Cob girth: The maize + legume intercropping and nitrogen management practices influenced the cob girth significantly (Table 2). Maximum cob girth was noticed when the sole maize was sown at $60 \times 20 \mathrm{~cm}$ which was in parity with girth of the cob recorded in maize + cluster bean, maize + blackgram, maize + greengram intercropping systems. The lowest cob girth was recorded when sole maize was sown in skipped rows. However, it was on par with maize + greengram, maize + blackgram treatments and significantly lower to other treatments. Among the nitrogen management, application of recommended dose of nitrogen to maize resulted in highest cob girth which was comparable with that of 75 per cent recommended dose of nitrogen application and both were significantly superior to application of nitrogen at 50 per cent recommended dose.

Number of grains per cob: The number of grains per cob was influenced by maize + legume intercropping and nitrogen management practices (Table 2). Maximum number of grains per cob was noticed when the sole maize was sown at $60 \times 20 \mathrm{~cm}$ which was in parity with grain number recorded in maize + cluster bean, maize + blackgram and maize + greengram intercropping systems. The lowest number of grains per cob was recorded when sole maize was sown in skipped rows. Among the nitrogen management, application of recommended dose of nitrogen to maize resulted in highest number of grains per cob which was comparable with 75 per cent recommended dose of nitrogen application and both were significantly superior to application of nitrogen at 50 per cent recommended dose.

Hundred grain weight: The hundred grain weight of maize was significantly influenced by maize + legume intercropping and doses of nitrogen application to maize (Table 2). Highest hundred grain weight was noticed when the sole maize was sown at $60 \times 20 \mathrm{~cm}$ which was similar with hundred grain weight recorded in maize + cluster bean, maize + blackgram and maize + greengram intercropping systems. The lowest number of grains per cob was recorded when sole maize was sown in skipped rows. However, it is on par with maize + greengram treatment and significantly lower to all other treatments. Among the nitrogen management, application of recommended dose of nitrogen to maize resulted in highest hundred grain weight which was comparable with 75 per cent recommended dose of nitrogen application. Significantly lowest hundred grain weight was recorded when nitrogen was applied at 50 per cent recommended dose.

\section{Grain yield and stover yield of maize}

The grain and stover yield of maize as influenced either by maize + legume intercropping or nitrogen management was found similar varying only in quantity (Table 2). The maximum grain and stover yield was recorded when sole maize was sown at $60 \times 20 \mathrm{~cm}$, which was statistically on par with the yields recorded with maize + cluster bean, maize + blackgram and maize + greengram intercropping in the order of decrease. The grain and stover yield recorded with sole maize in skipped rows was significantly lower to all other treatments. Among the nitrogen 
management, application of recommended dose of nitrogen to maize resulted in highest grain and stover yield which was comparable with that of 75 per cent recommended dose of nitrogen application. Significantly lowest yield of grain and stover was recorded when 50 per cent recommended dose of nitrogen applied to maize.

\section{Harvest index of maize}

Regarding harvest index of maize was concerned neither maize + legume intercropping nor nitrogen management did not exert any significant influence. Numerically higher value of harvest index was found when sole maize was sown in skipped rows. Among nitrogen management it was higher with 75 per cent recommended dose of nitrogen application to maize.

Table 2. Yield attributes and yield of maize as influenced by maize + legume intercropping and nitrogen management

\begin{tabular}{|c|c|c|c|c|c|c|c|}
\hline Treatment & $\begin{array}{c}\text { Cob } \\
\text { length } \\
(\mathrm{cm})\end{array}$ & $\begin{array}{l}\text { Cob } \\
\text { girth } \\
(\mathrm{cm})\end{array}$ & $\begin{array}{c}\text { No. of } \\
\text { grains per } \\
\text { cob }\end{array}$ & $\begin{array}{c}100 \text { grain } \\
\text { weight } \\
(\mathrm{g})\end{array}$ & $\begin{array}{c}\text { Grain yield } \\
\left(\mathrm{kg} \mathrm{ha}^{-1}\right)\end{array}$ & $\begin{array}{c}\text { Stover } \\
\text { yield }(\mathrm{kg} \\
\left.\mathrm{ha}^{-1}\right)\end{array}$ & $\begin{array}{c}\text { Harvest } \\
\text { index }\end{array}$ \\
\hline \multicolumn{8}{|l|}{ Crop combination } \\
\hline $\mathrm{T}_{1}$ : Maize $60 \times 20 \mathrm{~cm}$ & 14.4 & 14.7 & 333 & 28.8 & 4009 & 5921 & 40.4 \\
\hline $\mathrm{T}_{2}$ : Maize skipped row & 12.1 & 12.9 & 252 & 23.8 & 3071 & 4277 & 41.8 \\
\hline $\mathrm{T}_{3}: \mathrm{T}_{2}+$ Greengram & 13.7 & 13.4 & 297 & 26.4 & 3791 & 5685 & 40.0 \\
\hline $\mathrm{T}_{4}: \mathrm{T}_{2}+$ Blackgram & 13.9 & 14.4 & 299 & 27.5 & 3864 & 5771 & 40.1 \\
\hline $\mathrm{T}_{5}: \mathrm{T}_{2}+$ Cluster bean & 14.4 & 14.6 & 324 & 27.7 & 3905 & 5825 & 40.1 \\
\hline $\mathrm{SEm} \pm$ & 0.74 & 0.54 & 26.83 & 1.15 & 86.5 & 93.7 & 1.23 \\
\hline $\mathrm{CD}(\mathrm{P}=0.05)$ & 2.1 & 1.6 & 77 & 3.3 & 250 & 271 & NS \\
\hline \multicolumn{8}{|l|}{ Nitrogen management } \\
\hline $\begin{array}{c}\mathrm{N}_{1}: 100 \% \text { Rec. } \mathrm{N} \text { to } \\
\text { maize }\end{array}$ & 14.8 & 14.6 & 333 & 28.1 & 3838 & 5809 & 39.7 \\
\hline $\begin{array}{c}\mathrm{N}_{2}: 75 \% \text { Rec. } \mathrm{N} \text { to } \\
\text { Maize }\end{array}$ & 14.5 & 14.3 & 324 & 27.7 & 3791 & 5694 & 40.0 \\
\hline $\begin{array}{c}\mathrm{N}_{3}: 50 \% \text { Rec. } \mathrm{N} \text { to } \\
\text { Maize }\end{array}$ & 12.3 & 13.0 & 245 & 24.7 & 3055 & 4984 & 38.0 \\
\hline $\mathrm{SEm} \pm$ & 0.57 & 0.42 & 20.78 & 0.88 & 79.2 & 83.4 & 1.01 \\
\hline $\mathrm{CD}(\mathrm{P}=0.05)$ & 1.6 & 1.2 & 60 & 2.5 & 229 & 241 & NS \\
\hline
\end{tabular}

Yield attributes viz., cob length and girth, number of grains $\operatorname{cob}^{-1}$ and 100 grain weight and grain yield of maize were maximum with sole maize at $60 \times 20 \mathrm{~cm}$ spacing, which were at par with maize + cluster bean, maize + blackgram and maize + greengram intercropping. The lowest parameters were observed with sole maize 
sown in skipped rows (Table.2). The superiority of $60 \mathrm{x} 20 \mathrm{~cm}$ was due to minimal competition of available resources leading to better plant growth, as reported by Singh and Singh (2001). The skipped row method of planting resulted in grain yield reduction to the extent of $23.3 \%$ compared to $60 \times 20 \mathrm{~cm}$ spacing might be due to intraspecific competition under closer intra row spacing. Similar findings were reported by Ramaswamy et al. (1996), Moses et al. (2000), Asmat Ullah et al. (2007) and Sahoo and Mahapatra (2004). The yield attributes achieved with maize + cluster bean, maize + blackgram and maize + greengram were as par with sole maize at $60 \times 20 \mathrm{~cm}$ spacing. In cereal legume intercropping, legume crops are capable of fixing atmospheric nitrogen which might have resulted in enhancing growth of the intercropped maize. Among the crop combinations, intercropping of legumes in skipped rows of maize increased the main crop yield to the tune of 22.2 to $15.5 \%$, compared to skipped rows of maize as sole crops. Similar results have been reported by Dasaraddi et al. (2002), Rana et al. (2006) and Sharma et al. (2008). Among the intercropped legumes, yield attributes and yields were numerically higher in cluster bean followed by blackgram and greengram. It indicates that cluster bean was more compatible with less competition to maize.

Table 3. Yield attributes and yield of different intercrops as influenced by maize + legume intercropping and nitrogen management

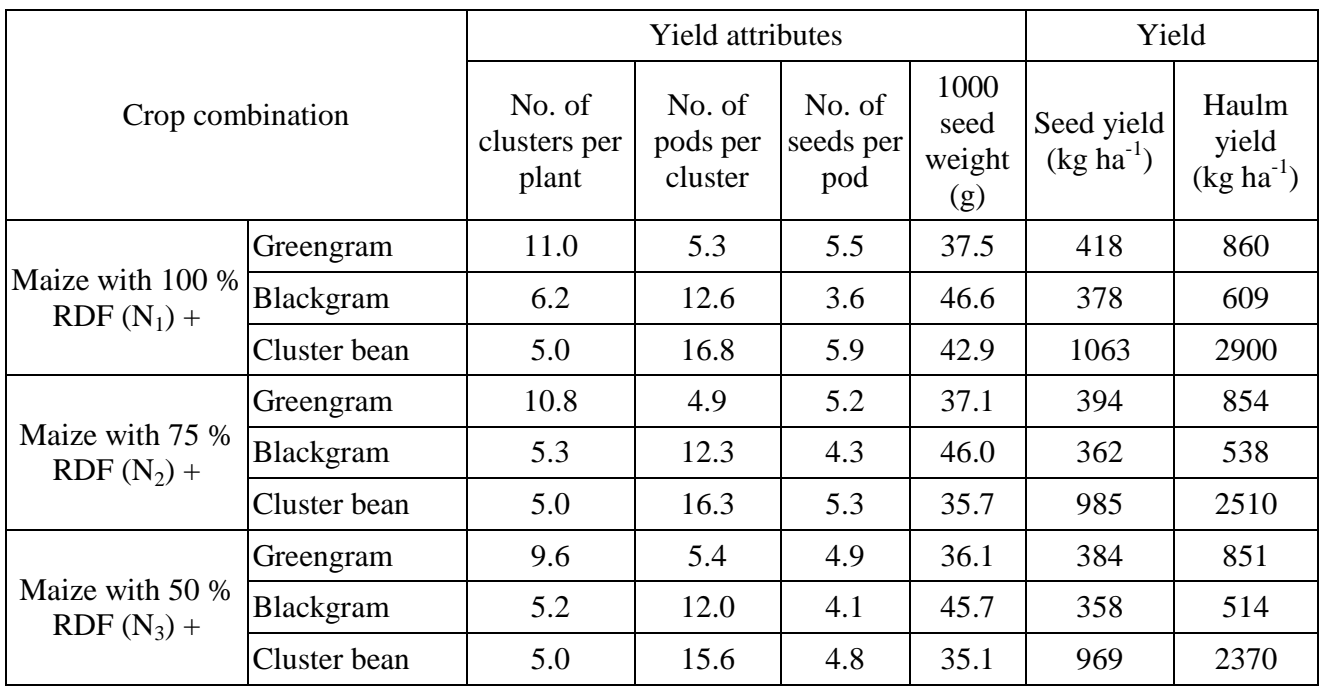

The parameters studied were highest with the application of $100 \%$ recommended dose of nitrogen to maize, but at par with $75 \%$ nitrogen to maize. Nitrogen being the major constituent of chlorophyll, whose intensity is known to increase with added nitrogen supply, might have promoted the plant growth. Analysis of grain yield data showed that increase in grain yield of sole crop of maize was due to positive effect of nitrogen, whereas that of maize + legume should be attributed to 
combined effect of nitrogen as well as complementary effect of legume association with maize. The findings of the present study are in accordance with those to Sharma (1994) and Khandkar and Nigam (1996).

\section{Yield attributes and yield of intercrops}

Yield attributes and yield of three intercrops viz., greengram, blackgram and cluster bean were highest with respective sole crops followed by application of 100 , 75 and $50 \%$ recommended dose of nitrogen to maize in the order of descent (Table 3 ). But the above said parameters of intercropped legumes did not deviate much from the respective sole crops. Shah et al. (1991) already found similar results. However, when the nitrogen level to maize was gradually decreased the yield attributes and yield of intercropped legumes was also found decreased. Green gram, blackgram and cluster bean suffered yield reduction to the extent of 4.0, 4.2, 7.3 and 8.1, 5.3, 8.8\% with the application of 75 and $50 \%$ nitrogen recommended dose to maize. This shows that legumes are capable to extend their positive effect at low fertility levels in association with non legumes. These results are in accordance with Barik (1997) and Halikatti and Banarasilal (1998).

Table 4. Maize equivalent yield $\left(\mathrm{kg} \mathrm{ha}^{-1}\right)$, land equivalent ratio, gross returns, net returns and BCR of maize as influenced by maize + legume intercropping and nitrogen management

\begin{tabular}{|c|c|c|c|c|c|}
\hline Treatment & $\begin{array}{c}\text { Maize grain } \\
\text { equivalent yield }\end{array}$ & $\begin{array}{l}\text { Land } \\
\text { equivalent } \\
\text { ratio }\end{array}$ & $\begin{array}{c}\text { Gross } \\
\underset{\left.\mathrm{ha}^{-1}\right)}{\text { returns }}(\mathrm{Rs}\end{array}$ & $\begin{array}{c}\text { Net } \\
\text { returns } \\
\left(\mathrm{Rs} \mathrm{ha}^{-1}\right)\end{array}$ & $\mathrm{BCR}$ \\
\hline \multicolumn{6}{|l|}{ Crop combination } \\
\hline $\mathrm{T}_{1}$ : Maize $60 \times 20 \mathrm{~cm}$ & 4009 & 1.000 & 37993 & 21654 & 2.32 \\
\hline $\mathrm{T}_{2}$ : Maize skipped row & 3071 & 1.000 & 28845 & 12506 & 1.76 \\
\hline $\mathrm{T}_{3}: \mathrm{T}_{2}+$ Greengram & 5535 & 1.883 & 49965 & 31541 & 2.71 \\
\hline $\mathrm{T}_{4}: \mathrm{T}_{2}+$ Blackgram & 5465 & 1.833 & 49491 & 31067 & 2.68 \\
\hline $\mathrm{T}_{5}: \mathrm{T}_{2}+$ Cluster bean & 5790 & 1.938 & 52145 & 33721 & 2.83 \\
\hline $\mathrm{SEm} \pm$ & 39.45 & 0.039 & 314.1 & 298.2 & 0.04 \\
\hline $\mathrm{CD}(\mathrm{P}=0.05)$ & 114 & 0.113 & 907 & 861 & 0.82 \\
\hline \multicolumn{6}{|l|}{ Nitrogen management } \\
\hline $\begin{array}{l}\mathrm{N}_{1}: 100 \% \text { Rec. } \mathrm{N} \text { to } \\
\text { maize }\end{array}$ & 5663 & 1.916 & 51113 & 32871 & 2.80 \\
\hline $\begin{array}{l}\mathrm{N}_{2}: 75 \% \text { Rec. } \mathrm{N} \text { to } \\
\text { maize }\end{array}$ & 5509 & 1.854 & 49766 & 32176 & 2.83 \\
\hline $\begin{array}{l}\mathrm{N}_{3}: 50 \% \text { Rec. } \mathrm{N} \text { to } \\
\text { maize }\end{array}$ & 4742 & 1.655 & 42920 & 25982 & 2.53 \\
\hline $\mathrm{SEm} \pm$ & 37.13 & 0.038 & 307.2 & 278.1 & 0.04 \\
\hline $\mathrm{CD}(\mathrm{P}=0.05)$ & 107 & 0.110 & 888 & 803 & 0.12 \\
\hline
\end{tabular}




\section{Maize equivalent yield and land equivalent ratio}

As indicated in table 4, the maize equivalent yield and land equivalent ratio was higher with maize + cluster bean intercropping followed by maize + greengram and maize + blackgram. With regards to nitrogen management to maize, significant superiority of maize equivalent yield and land equivalent ratio was found with application of $100 \%$ recommended dose of nitrogen to maize.

\section{Gross returns, net returns and B.C ratio}

Gross and net returns were significantly influenced by maize+legume intercropping as well as nitrogen management (Table 4). The highest gross and net returns were realized with the maize + cluster bean intercropping which was significantly superior to all other treatments. The gross and net returns estimated with maize + greengram and maize + blackgram intercropping were statistically on par with each other but significantly higher to that of sole maize at $60 \times 20 \mathrm{~cm}$. Significantly, lowest gross and net returns was recorded when sole maize was planted in skipped rows.

As regards the nitrogen management, graded decrease in recommended dose of nitrogen to maize gradually decreased the gross and net returns with significant disparity between 100, 75 and 50 per cent recommended dose of nitrogen.

Maximization of income from the farm produce is most desirable criterion for any peasant. Intercropping in maize improved the monetary value of the total productivity compared to the respective sole crops, which might be due to additional yield of intercrops. The benefit cost ratio was significantly higher with maize + cluster bean intercropping as compared to other treatments. This was due to the benefits realized with high seed yield of cluster bean and maize, with lower cost of cultivation. These are in accordance with those of Parvender et al. (2009), and Dilip and Nepalia (2009). The respective lowest values were associated with sole maize in skipped rows. Regarding nitrogen management to maize, application of $100 \%$ recommended dose of nitrogen to maize resulted in higher benefit cost ratio but at par with application of $75 \%$ recommended dose of nitrogen to maize.

\section{Nitrogen uptake and dynamics of soil available nitrogen}

Sole maize at $60 \times 20 \mathrm{~cm}$ and application of $100 \%$ recommended dose of nitrogen to maize resulted in highest uptake of nitrogen followed by maize + greengram, maize + black gram and maize+ cluster bean (Table 5).The highest values with sole maize at $60 \times 20 \mathrm{~cm}$ was due to minimum competition from the intercrops and as a result the available nitrogen utilized effectively. Intercropped maize with associated legumes have created better microbial environment and maintained better nitrogen dynamics in soil, assist in better uptake of nutrients. Lowest nitrogen uptake was estimated with sole maize sown in skipped rows and with $50 \%$ recommended dose of nitrogen to maize. The net gain of post harvest soil available nitrogen was higher with maize + greengram, with the application of $100 \%$ recommended dose of 
nitrogen to maize and the net loss of soil available nitrogen was with sole maize sown in skipped rows at 50\% recommended dose of nitrogen. Thus, inclusion of legume with maize either improved or maintained the available nitrogen status of soil due to its root nodulation. Among the three legumes tested, the improvement in soil available nitrogen was maximum with greengram followed by blackgram and cluster bean.

Table 5. Soil available nitrogen balance $\left(\mathrm{kg} \mathrm{ha}^{-1}\right)$ as influenced by maize + legume intercropping and nitrogen management

\begin{tabular}{|l|c|c|c|c|c|c|}
\hline \multirow{2}{*}{ Treatment } & $\begin{array}{c}\text { Initial } \\
\text { nitrogen }\end{array}$ & $\begin{array}{c}\text { Added } \\
\text { nitrogen }\end{array}$ & $\begin{array}{c}\text { Removed } \\
\text { nitrogen }\end{array}$ & $\begin{array}{c}\text { Computed } \\
\text { balance }\end{array}$ & $\begin{array}{c}\text { Post } \\
\text { experiment } \\
\text { nitrogen in soil }\end{array}$ & $\begin{array}{c}\text { Net gain } \\
\text { or loss }\end{array}$ \\
\cline { 2 - 7 } & 1 & 2 & 3 & $(2-3)$ & 4 & $(4-1)$ \\
\hline $\mathrm{T}_{1} \mathrm{~N}_{1}$ & 168 & 240 & 124 & 116 & 181 & 13 \\
\hline $\mathrm{T}_{1} \mathrm{~N}_{2}$ & 168 & 180 & 115 & 65 & 162 & -6 \\
\hline $\mathrm{T}_{1} \mathrm{~N}_{3}$ & 168 & 120 & 80 & 40 & 143 & -25 \\
\hline $\mathrm{T}_{2} \mathrm{~N}_{1}$ & 168 & 240 & 96 & 114 & 136 & -32 \\
\hline $\mathrm{T}_{2} \mathrm{~N}_{2}$ & 168 & 180 & 87 & 93 & 124 & -44 \\
\hline $\mathrm{T}_{2} \mathrm{~N}_{3}$ & 168 & 120 & 73 & 47 & 114 & -54 \\
\hline $\mathrm{T}_{3} \mathrm{~N}_{1}$ & 168 & $240+20^{*}$ & $114+21^{* *}$ & 125 & 196 & 28 \\
\hline $\mathrm{T}_{3} \mathrm{~N}_{2}$ & 168 & $180+20^{*}$ & $96+20^{* *}$ & 84 & 174 & 6 \\
\hline $\mathrm{T}_{3} \mathrm{~N}_{3}$ & 168 & $120+20^{*}$ & $86+18^{* *}$ & 36 & 160 & -8 \\
\hline $\mathrm{T}_{4} \mathrm{~N}_{1}$ & 168 & $240+20^{*}$ & $121+29^{* *}$ & 110 & 187 & 19 \\
\hline $\mathrm{T}_{4} \mathrm{~N}_{2}$ & 168 & $180+20^{*}$ & $89+24^{* *}$ & 87 & 169 & 1 \\
\hline $\mathrm{T}_{4} \mathrm{~N}_{3}$ & 168 & $120+20^{*}$ & $80+22^{* *}$ & 38 & 154 & -14 \\
\hline $\mathrm{T}_{5} \mathrm{~N}_{1}$ & 168 & $240+20^{*}$ & $101+34^{* * *}$ & 125 & 183 & 15 \\
\hline $\mathrm{T}_{5} \mathrm{~N}_{2}$ & 168 & $180+20^{*}$ & $93+29^{* *}$ & 78 & 170 & 2 \\
\hline $\mathrm{T}_{5} \mathrm{~N}_{3}$ & 168 & $120+20^{*}$ & $85+25^{* *}$ & 30 & 150 & -18 \\
\hline
\end{tabular}

* Nitrogen added to intercrop

** Nitrogen removed by intercrop

In conclusion, the result revealed that among the different maize intercropping tested, maize in skipped rows + cluster bean with $75 \%$ recommended dose of nitrogen to maize was found higher grain maize equivalent yield as well as profitable to the farmers, besides sustaining the soil fertility. 


\section{REFERENCES}

Ullah, A., Bhatti, Bhatti, A.M., Gurmani, Z.A. and Imran, M. 2007. Studies on planting patterns of maize (Zea mays L.) facilitating legumes intercropping. Journal of Agricultural Research, 45(2):113-118

Barik, K.C. 1997. Maize + legume intercropping for north central plateau of Orissa. Legume Research, 20(3/4):218-220

Dasaraddi, S.V., Hiremeth, S.M. and Patil, R.H. 2002. Performance of legumes as intercrop in maize. Bangladesh Agricultural University Research Journal, 14(2):241-244

Singh, D. and Nepalia. V. 2009. Influence of integrated nutrient management on quality protein maize (Zea mays) productivity and soils of Rajasthan. Indian journal of Agricultural Sciences, 79(12): 1020-1022

Halikatti, S.I. and Banarasilal. 1998. Production potential of maize as influenced by planting geometry, mulching and grain legume intercropping. Karnataka Journal of Agricultural Sciences, 11(4): 883-888

Khandkhar, U.R. and Nigam, K.B. 1996. Effect of maize legume intercropping systems on soil fertility. Indian journal of Agricultural Sciences, 66(1): 601-603

Kaire, M., Ikramullah, M. and Mohammad, S. 2000. Performance of maize in intercropping with legumes at different levels of fertilizers. Crop Research, 20(1): 149-151

Panse, V.G. and Sukhatme, P.V. 1985. Statistical methods for Agricultural workers. Indian Council of Agricultural Research, New Delhi

Parvender Sheoran, Virender Sardana, Sukhvinder Singh and Sher Singh. 2009. Productivity potential and economic feasibility of maize (Zea mays)- greengram based intercropping (Vigna radiata) intercropping system under rainfed conditions. Indian Journal of Agricultural Sciences, 79 (7):535-537

Ramaswamy, M., Vairavan, K. and Srinivasan, K. 1996. Production potential and economics of cereal based cropping system in red lateritic soils of Pudukkotai district. Madras Agricultural Journal, 83(4): 236-239

Rana, K.S., Shivran, R.K. and Ashok Kumar. 2006. Effect of moisture- conservation practices in productivity and water use in maize (Zea mays)- based intercropping system under rainfed conditions. Indian journal of Agronomy, 51(1): 24-26

Sahoo, S.C. and Mahapatra, P.K. 2004. Response of sweet corn (Zea mays) to nitrogen levels and plant population. Indian journal of Agricultural Sciences, 74(6): 337-338.

Shah, M.H., Kaul, D.K. Knandoy, B.A. and Kachroo, D. 1991. Production potential and monetary advantage index of maize intercropped with different grain legumes. Indian journal of Agronomy, 36(1): 23-28

Sharma, J. 1994. Effect of fertility levels on maize and legume intercropping system under rainfed condition. Indian journal of Agronomy, 39(3): 382-385

Sharma, R.P. Singh, A.K., Paddar, B.K. and Raman, K.R. 2008. Forage production potential and economics of maize (Zea mays) with legumes intercropping under various row proportions. Indian journal of Agronomy, 53(2): 121-124

Singh, V.P. and Singh.V.K. 2001. Productivity potential and economics of maize (Zea mays) and soybean ( Glycine max) intercropping patterns under rainfed low hill or valley situations of Uttaranchal. Indian journal of Agronomy, 46(1): 27-31 